J. Dairy Sci. 92:2151-2158

doi:10.3168/jds.2008-1255

(c) American Dairy Science Association, 2009.

\title{
Genetic analysis of lactoferrin content in bovine milk
}

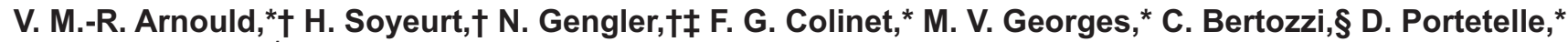 \\ and R. Renaville*1 \\ *Animal and Microbial Biology Unit, and \\ †Animal Science Unit, Gembloux Agricultural University, B-5030 Gembloux, Belgium \\ $\ddagger$ National Fund for Scientific Research, B-1000 Brussels, Belgium \\ §Walloon Breeders Association, B-5530 Ciney, Belgium
}

\section{ABSTRACT}

Bovine lactoferrin (LF) is mainly present in milk and shows important physiological and biological functions. The aim of this study was to estimate the heritability and correlation values of LF content in bovine milk with different economic traits as milk yield (MY), fat and protein percentages, and somatic cell score (SCS). Variance components of the studied traits were estimated by REML using a multiple-trait mixed model. The obtained heritability (0.22) for LF content predicted using mid-infrared spectrometry ( $\mathrm{pLF}$ ) suggested the possibility of animal selection based on the increase of LF content in milk. The phenotypic and genetic correlation values calculated between pLF and SCS were moderate (0.31 and 0.24 , respectively). Furthermore, a preliminary study of bovine $L F$ gene polymorphism effects was performed on the same production traits. By PCR, all exons of the $L F$ gene were amplified and then sequenced. Three new polymorphisms were detected in exon 2, exon 11, and intron 8 . We examined the effects of $L F$ gene polymorphisms of exons 2, 4, 9, 11, and 15, and intron 8 on $\mathrm{pLF}, \mathrm{MY}$, fat and protein percentages, and SCS. The different observed effects did not reach a significant level probably because of the characteristics of the studied population. However, the results were promising, and LF may be a potential indicator of mastitis. Further studies are necessary to evaluate the effect of genetic selection based on LF content on the improvement of mastitis resistance.

Key words: lactoferrin, genetic parameter, gene polymorphism, mastitis

\section{INTRODUCTION}

Lactoferrin (LF) is a single-chain, iron-binding glycoprotein of $80 \mathrm{kDa}$ that belongs to the serum transferrin gene family. Called the red protein, LF is present in

Received April 9, 2008.

Accepted December 8, 2008.

${ }^{1}$ Corresponding author: renaville.r@fsagx.ac.be milk but also in other exocrine secretions such as tears, semen, saliva, and cervical mucus (Wakabayashi et al., 2006). The protein is synthesized by granulocytes and mammary epithelial cells in response to infections such as mastitis (Kaminski et al., 2006). Lactoferrin is able to sequester 2 molecules of iron making them unavailable to pathogenic organisms. In addition to this bacteriostatic activity, LF is endowed with antifungal and bactericidal effects (Wakabayashi et al., 2006). Indeed, LF can interact with the lipid A of LPS contained in bacterial membrane. Lactoferrin can affect the destabilization of gram-negative bacterial membranes by preventing LPS from interacting with the main actors of LPS signaling such as CD14 (Baveye et al., 1999; Rainard and Riollet, 2006). Further, LF modulates the inflammatory process, immune system response, and cell growth. This multifunctional protein plays a key role in the health of mammary gland. Thus, it could be considered as a potential candidate gene in dairy mastitis resistance selection (Seyfert et al., 1996; WojdakMaksymiec et al., 2006).

The LF gene is mapped on Bos taurus autosome (BTA) 22q24 and consists of 17 exons. The promoter region is 1,122 bp long (Schwerin et al., 1994; Kaminski et al., 2006). Seyfert and Kühn (1994) detected 6 polymorphisms in the $5^{\prime}$ flanking region and 1 in exon 1. Li et al. (2004) discovered 6 other SNP: 1 in exon 4, 1 in intron 4, 1 in exon 8,2 in exon 9, and 1 in exon 15. In this chromosomal region, Boichard et al. (2003) identified a QTL for milk fat percentage and Ashwell et al. (2004) reported significant effects for milk protein percentage and SCS. Harder et al. (2006) also detected QTL affecting persistency of fat and protein yield between $L F$ gene and HMH1R marker in German Holstein dairy cattle.

Recently, Soyeurt et al. (2007) developed a calibration equation for predicting an indicator of LF content using mid-infrared (MIR) spectrometry. This technology allows the analysis of a large number of milk samples (up to 500 samples/h for the MilkoScan FT6000; Foss, Hillerød, Denmark). Even if the accuracy of this method is lower than that observed for a reference chemical 
analysis such as ELISA or immunodiffusion methods (which present the inconvenience of requiring time and skilled staff), MIR spectrometry could substitute those methods in research applications. Furthermore, this method is already used by milk laboratories involved in routine milk recording for predicting other production traits such as percentages of fat, protein, and lactose.

The objective of this study was to estimate the heritability and correlation values of LF content in milk predicted by MIR spectrometry ( $\mathbf{p L F}$ ) with other milk production traits as milk yield (MY), fat (\%Fat) and protein percentages (\%Protein) and SCS. The second objective was to perform a preliminary study of its gene polymorphism effects on pLF and on milk production traits.

\section{MATERIALS AND METHODS}

\section{Genetic Parameters}

Data. During routine milk recording in Walloon, 13,012 milk samples were collected from April 2005 to May 2007, and analyzed by using a MilkoScan FT6000 (Foss). All generated spectra were recorded and stored. Simultaneously, \%Fat, \%Protein, and SCS were estimated and recorded. The content of LF used in this study was estimated (pLF, mg/L) by MIR spectrometry from the calibration equation developed by Soyeurt et al. (2007). Some cows were dried off or calved during this experiment; the number of test-days with recorded spectra was not constant for all cows. To increase the number of contemporaries, MY (kg/d), \%Fat, \%Protein, and SCS known for all studied cows and herds since January 1993 were added. Test-day records before 5 DIM and after 365 DIM were deleted. Lactations were grouped as first, second, and third or later lactations. The frequencies of lactation numbers were 32.8, 23.7, and $43.5 \%$, respectively. Age at test-day was defined as the number of months from birth. There were 9 classes of age (for first lactation, age $<29,29$ to 32 , and $\geq 33$ mo; for second lactation, $<42,42$ to 46 , and $\geq 47 \mathrm{mo}$; and for the third and greater lactation, age $<54,54$ to 59 , and $\geq 60 \mathrm{mo})$. The final edited data set included 132,040 test-day records from 6,256 cows belonging to 25 herds and 7 breeds.

Estimation of Variance Components and Prediction Error Variances. The variance components of the studied traits and the corresponding standard errors were estimated by average information-REML (Misztal, 2007). The multiple-trait mixed model used was

$$
\mathbf{y}=\mathbf{X} \boldsymbol{\beta}+\mathbf{W} \mathbf{k}+\mathbf{Z} \mathbf{p}+\mathbf{Z u}+\mathbf{e}
$$

where $\mathbf{y}$ was the vector of observations (MY, \%Fat, \%Protein, SCS, and pLF); $\boldsymbol{\beta}$ was the vector of fixed effects (herd $\times$ test-day $\times$ class of lactation number, class of age $\times$ class of lactation number, and regression on breed composition); $\mathbf{k}$ was the vector of permanent environment random effects within lactation; $\mathbf{p}$ was the vector of permanent environment across lactations; $\mathbf{u}$ was the vector of additive genetic animal effects; $\mathbf{W}, \mathbf{X}$, and $\mathbf{Z}$ were incidence matrices; and $\mathbf{e}$ was the vector of random residual effects. The pedigree contained 10,230 animals (8,821 dams and 1,326 sires).

Prediction error variance (PEV) was estimated (Misztal, 2007) with a mixed-model solving program using direct sparse inversion of the coefficient matrix. Program was modified to permit direct extraction of the elements of the inverse coefficient matrix. Additional details about PEV estimation were mentioned by Tosh and Wilton (1994).

\section{Polymorphism Study}

Data. Using a multiple-trait mixed model, Soyeurt et al. (2007) estimated pLF EBV for 1,910 cows. Based on these results, 261 cows from 7 breeds (Brown-Swiss, dual-purpose Belgian Blue, Holstein, Jersey, Montbeliarde, Non-Holstein Meuse-Rhine-Yssel type Red and White, and Normande; Table 1) were selected with low $(\mathrm{n}=134)$ or high pLF EBV $(\mathrm{n}=127)$. A large number of cows were, to a certain extent, crossbred and their breed composition was traced back to purebred ancestors.

Polymorphism Discovery. Discovery of polymorphisms was based on DNA samples of 20 Holstein sires, selected from their SCS EBV (high or low). These DNA samples were used as templates in PCR to amplify each of the 17 exons of the $L F$ gene.

Table 2 describes the sequences of the used primers pairs for each exon, their respective annealing temperatures, expected lengths of PCR products, and the number of cycles. For all primers, the first step of denaturation was at $95^{\circ} \mathrm{C}$ for $5 \mathrm{~min}$ and $95^{\circ} \mathrm{C}$ for 30 s. Annealing was at temperatures given in Table 2 for $30 \mathrm{~s}$. Extension was at $72^{\circ} \mathrm{C}$ for $30 \mathrm{~s}$ and the reaction was carried out for several cycles (Table 2). The final extension was at $72^{\circ} \mathrm{C}$ for $10 \mathrm{~min}$. The PCR mix $(25$ $\mu \mathrm{L}$ ) contained $\mathrm{H}_{2} \mathrm{O}, 2.5 \mu \mathrm{L}$ of $10 \times$ PCR buffer $(500$ $\mathrm{m} M \mathrm{KCl}, 15 \mathrm{mM} \mathrm{MgCl} 2,100 \mathrm{~m} M$ Tris, $\mathrm{pH} 9.0$ at room temperature), $1 \mu \mathrm{L}$ of deoxynucleotide triphosphates (GE Healthcare, Buckinghamshire, UK) at $200 \mu M$ final concentration, each primer (Sigma-Proligo, The Woodlands, TX) at $100 \mu M$ final concentration, and 1 U of Taq DNA polymerase (GE Healthcare). Amplified 
Table 1. Average breed composition (in \%) of the studied population of cows $(\mathrm{n}=261)$ with the lowest $(\mathrm{n}=$ $134)$ and highest $(\mathrm{n}=127)$ predicted lactoferrin content $(\mathrm{pLF}) \mathrm{EBV}$

\begin{tabular}{lccc}
\hline Breed & Composition & Lowest pLF EBV & Highest pLF EBV \\
\hline Dual-purpose Belgian Blue & 8.7 & 7.1 & 10.3 \\
Non-Holstein Red & 4.7 & 3.9 & 5.5 \\
Holstein & 56.0 & 58.9 & 52.9 \\
Jersey & 4.6 & 5.2 & 3.9 \\
Brown-Swiss & 1.0 & 0.6 & 1.6 \\
Montbeliarde & 15.1 & 15.4 & 14.8 \\
Normande & 9.9 & 8.9 & 11.0 \\
\hline
\end{tabular}

fragments were visualized by $2 \%$ agarose gel electrophoresis stained with ethidium bromide.

The amplified products were purified using Montage PCR filter units (Millipore, Billerica, MA) and directly sequenced by using the BigDye terminator v3.1 cycle sequencing kit (Applied Biosystems, Foster City, CA). Sequencing reactions were resolved on an ABI Prism 3100 automated capillary DNA sequencer (Applied Biosystems). Polymorphisms were identified by visually inspecting each base in sequencing traces and by multiple sequence alignment with ClustalW (Chenna et al., 2003).
DNA Extraction from Milk. One milk sample was taken from each cow $(\mathrm{n}=261)$ in various phases of lactation and the DNA was extracted from somatic cells using the NucleoSpin Tissue kit (Machery-Nagel \& Co., Düren, Germany) with an adapted procedure. The milk samples $(50 \mathrm{~mL})$, conserved at $-20^{\circ} \mathrm{C}$, were centrifuged for 15 min at $5,000 \times g$ and the supernatant was discarded. To lyse cells, the pellet (approximately 2 $\mathrm{mL}$ ) was recovered and resuspended with $2 \mathrm{~mL}$ of lysis buffer and $150 \mu \mathrm{L}$ of proteinase $\mathrm{K}$. The suspension was vortexed for $10 \mathrm{~s}$ and incubated for $10 \mathrm{~min}$ at $70^{\circ} \mathrm{C}$. To precipitate the DNA, the solution was cooled to ambi-

Table 2. Primer sequences, PCR conditions, and product lengths designed from the bovine lactoferrin gene and used in amplification of genomic fragments

\begin{tabular}{|c|c|c|c|c|c|}
\hline Exon & Primer & Sequence & $\mathrm{Ta}^{1}\left({ }^{\circ} \mathrm{C}\right)$ & Cycles (n) & Product length (bp) \\
\hline \multirow[t]{2}{*}{1} & $\mathrm{P} 1 \mathrm{~F}$ & 5'-CCC CGC TCT TCC CCC TT-3' & 64 & 40 & 284 \\
\hline & P1R & 5'-CCC CGC CCC CAC TCA TA-3' & & & \\
\hline 2 & $\mathrm{P} 2 \mathrm{~F}$ & 5'-GAC CGT CTC TTC CAG GG-3' & 52 & 40 & 230 \\
\hline \multirow[t]{2}{*}{3} & P3F & 5'-CTC GTC TGG CCT GTG TTT-3 & 56 & 30 & 281 \\
\hline & P3R & $5^{\prime}$-GCC TCC TCT GCT TCC C-3' & & & \\
\hline 4 & $\mathrm{P} 4 \mathrm{~F}$ & 5'-TCT GGT TCA CGC TAA GAG CT-3' & 60 & 40 & 270 \\
\hline \multirow[t]{2}{*}{6} & $\mathrm{P} 6 \mathrm{~F}$ & 5'-TCT CTA GCC AGC ATC CTC T-3 & 63 & 45 & 550 \\
\hline & $\mathrm{P} 6 \mathrm{R}$ & $5^{\prime}$-AAG ACT ACA TCT GTC TCG GA-3' & & & \\
\hline \multirow[t]{2}{*}{$7-8$} & $\mathrm{P} 7 \mathrm{~F}$ & 5'-GAC AAC TTG CCA GAG AAG GC-3' & 62 & 30 & 229 \\
\hline & $\mathrm{P} 8 \mathrm{R}$ & 5'-GCT CAC CAC CCA CAC CG-3' & & & \\
\hline \multirow[t]{2}{*}{9} & $\mathrm{P} 9 \mathrm{~F}$ & 5'-CGG GGT GAA CGG GGA G-3' & 65 & 40 & 350 \\
\hline & P9R & 5'-GGC AGG CAG GAC GAG C-3' & & & \\
\hline 12 & $\mathrm{P} 12 \mathrm{R}$ & 5'-CCG CTT ACA CCA AAC GAG-3' & & & \\
\hline \multirow[t]{2}{*}{13} & $\mathrm{P} 13 \mathrm{~F}$ & 5'-TTT GCT GAA TCC TGT TGG-3' & 53 & 30 & 392 \\
\hline & P13R & 5'-AAT GAA ATG TGA TGT GCC-3' & & & \\
\hline \multirow[t]{2}{*}{14} & $\mathrm{P} 14 \mathrm{~F}$ & 5'-GTG TTT ACC TCT CTG GCA ATG-3' & 50 & 40 & 300 \\
\hline & P14R & $5^{\prime}$-TGG TGA CGG CAA GGA T-3' & & & \\
\hline \multirow[t]{2}{*}{15} & $\mathrm{P} 15 \mathrm{~F}$ & 5'-CGG TGG GTG GTC ACA GC-3' & 57.5 & 40 & 376 \\
\hline & P15R & $5^{\prime}$-GGC ACG AGG AAG AAT GGC-3' & & & \\
\hline \multirow[t]{2}{*}{16} & $\mathrm{P} 16 \mathrm{~F}$ & 5'-GAT TGC CTC CCA AGT CCA-3' & 51 & 40 & 353 \\
\hline & P16R & $5^{\prime}$-TAA ACC CAC ATC ACC CCT A-3' & & & \\
\hline \multirow[t]{2}{*}{17} & $\mathrm{P} 17 \mathrm{~F}$ & 5'-GCT TGA CCT ACA GTG GGG-3' & 61 & 40 & 409 \\
\hline & P17R & 5'-GGT CCA GAC ACG ATT TCA G-3' & & & \\
\hline
\end{tabular}

\footnotetext{
${ }^{1} \mathrm{Ta}=$ temperature of annealing.
} 
Table 3. Primer sequences and primer lengths used in single-base extension

\begin{tabular}{llc}
\hline Primer & Sequence & Size (bp) \\
\hline SNP_2 & (GACT)2 GTA CCA TCT CCC AAC C & 24 \\
SNP_4 & (GACT)5 GGT CCG CTG GGT GG & 34 \\
SNP_8 & (GACT)3 ATT CGG CGC TGT ACC T & 28 \\
SNP_9 & (GACT)9 CAC TTC TTC TGC TCC TC & 51 \\
SNP_11 & (GACT)7 TGT GTG CTG AGA CCA AC & 45 \\
\hline
\end{tabular}

ent temperature and $2 \mathrm{~mL}$ of ethanol $96 \%$ was added. The obtained solution was vortexed. Approximately 2 $\mathrm{mL}$ of precipitated DNA were applied onto a NucleoSpin Tissue column and centrifuged for $1 \mathrm{~min}$ at 11,000 $\times g$ before 2 washing steps. First, $500 \mu \mathrm{L}$ of wash buffer was added and the column was centrifuged for $1 \mathrm{~min}$ at $11,000 \times g$. Second, $600 \mu \mathrm{L}$ of buffer B5 was added and the column was centrifuged for $1 \mathrm{~min}$ at $11,000 \times$ g. The silica membrane was then dried by centrifugation for $1 \mathrm{~min}$ at $11,000 \times g$. For DNA elution, 50 $\mu \mathrm{L}$ of prewarmed elution buffer $\left(70^{\circ} \mathrm{C}\right)$ was added onto the column and incubated sheltered from light at room temperature for 5 min. Finally, the column was centrifuged for $1 \mathrm{~min}$ at $11,000 \times g$. The DNA was conserved at $4^{\circ} \mathrm{C}$ until genotyping.

Genotype Assessment. The single-base extension (SBE) method was developed to study the variability of the SNP discovered in the 20 bulls of the 261 cows on each DNA sample. The SBE method allows the simultaneous study of several SNP. The SBE reaction was applied for SNP located on exons 2, 4, 9, and 11 and on intron 8. These 4 exons and the intron were amplified by PCR. The PCR products were pooled and purified using the High-Pure PCR Product Purification Kit (Roche Diagnostics GmbH, Mannheim, Germany). The purified products were used as templates for the primer extension reaction performed with the SNaPshot Multiplex kit (Applied Biosystems). The SBE primers (Sigma-Proligo) purified by HPLC are listed in Table 3. The PCR conditions were the same as described above. The SBE reaction was set using the SNaPshot Multiplex kit (Applied Biosystems). To remove unincorporated dNTPs, 1 unit of calf intestinal alkaline phosphatase (Roche Diagnostics $\mathrm{GmbH}$ ) was added to the reaction mixture. The mixture was incubated at $37^{\circ} \mathrm{C}$ for $1 \mathrm{~h}$, followed by $15 \mathrm{~min}$ at $72^{\circ} \mathrm{C}$ for enzyme inactivation. The samples containing extension products and Genescan 120 LIZ size standard solution were added to HiDi formamide according to the manufacturer's recommendation. Mixture was incubated at $95^{\circ} \mathrm{C}$ for $5 \mathrm{~min}$, followed by $5 \mathrm{~min}$ on ice. Electrophoresis was performed on an ABI Prism 3100 Genetic Analyzer. The results were analyzed using the program of GeneScan Analysis Software v3.7 (Applied Biosystems).
Selective PCR amplification of one of the alleles was used on exon 15. The used allele-specific PCR primers were P15-FT 5'-CTG TGG TGT CTC GGA GCA AT3', P15-FC 5'-CTG TGG TGT CTC GGA GCA AC-3', and P15-R 5'-GAA ACT CAA CTC TCT ACC TGG $\mathrm{C}-3^{\prime}$. The PCR conditions were the same as described above. Annealing was at $63.5^{\circ} \mathrm{C}$ and the reaction was carried out for 45 cycles.

Polymorphism Association Study. To study LF SNP effects, the individual effects of genotyped cows were extracted from the same model as that used for variance component estimation. For each animal, average-lactation yield deviations (YD) were computed as the sum of EBV and the solution of the permanent environment across-lactation effects previously estimated. The permanent environment within lactation was not included because its expected value should be zero across repeated lactations. Based on the corrected phenotypic value and SNP data of the 261 analyzed animals, the effect of the 6 detected SNP on MY, \%Fat, \%Protein, pLF, and SCS were studied separately using the following single-trait mixed model:

$$
\mathbf{y}=\mathbf{X} \boldsymbol{\beta}+\mathbf{Z u}+\mathbf{e},
$$

where $\mathbf{y}$ was the vector containing the corrected phenotypic values defined as YD for all studied traits; $\boldsymbol{\beta}$ was the vector containing the regression coefficients, which represented the allele substitution effect at each polymorphism site for the studied traits; $\mathbf{u}$ was the vector of additive genetic effects; $\mathbf{X}$ and $\mathbf{Z}$ were incidence matrices; and $\mathbf{e}$ was the vector of random residual effects. The different YD were obtained with different levels of reliability. Therefore, records were weighted in the model using a parameter $\left(R_{(g+p)}^{2}\right)$ based on the reliability of each YD. This weight was calculated for each animal as follows:

$$
R_{(g+p)}^{2}=\frac{\left(\operatorname{var}_{G}+\operatorname{var}_{P}\right)_{R E M L}-\left[P E V_{G}+P E V_{P}+2 \operatorname{cov}\left(P E V_{G}, P E V_{P}\right)\right]}{\left(\operatorname{var}_{G}+\operatorname{var}_{P}\right)_{R E M L}},
$$

where $\operatorname{var}_{G}$ was the estimated genetic variance, $\operatorname{var}_{P}$ corresponded to the estimated variance for the permanent environment across lactations variance, $P E V_{G}$ was the estimated PEV for the genetic effect for the considered animal, and $P E V_{P}$ was the estimated PEV for the estimated permanent environment random effects across lactations for the considered animal. Variances used were those previously estimated. The residual variance corresponded to the permanent environmental variance across lactations. The SNP effects were estimating using a BLUP program (Misztal, 2007). 
Table 4. Descriptive statistics for the traits analyzed in the cow population

\begin{tabular}{lrrrcc}
\hline Trait & \multicolumn{1}{c}{$\mathrm{n}$} & \multicolumn{1}{c}{ Mean } & \multicolumn{1}{c}{ SD } & Skewness & Kurtosis \\
\hline Milk $(\mathrm{kg} / \mathrm{d})$ & 132,040 & 22.38 & 8.59 & 0.47 & 0.29 \\
Fat $(\%)$ & 132,040 & 4.08 & 0.79 & 0.68 & 1.91 \\
Protein $(\%)$ & 132,040 & 3.49 & 0.41 & 0.69 & 1.64 \\
Lactoferrin $(\mathrm{mg} / \mathrm{L})$ & 11,301 & 137.80 & 176.74 & 0.27 & 0.73 \\
SCS & 132,040 & 3.24 & 1.79 & 0.52 & 0.00 \\
\hline
\end{tabular}

\section{Significance Test}

The statistical significance of differences for the 6 studied SNP was evaluated using Student's $t$-test. The number of degrees of freedom was estimated with the following formula: $\mathrm{df}=\mathrm{n}-\operatorname{rang}(\mathbf{X})$, where $\mathrm{n}$ was the observation number, and $\mathbf{X}$ was the incidence matrix. The following formula was applied to estimate the $t$ value:

$$
t=\frac{|\alpha|}{\sqrt{\sigma_{\alpha}^{2}}},
$$

where $\alpha$ was the solution for the considered trait and effect; $\sigma_{\alpha}^{2}$ was the estimated variance obtained for the considered trait, a value that was equal to the diagonal element of the inverse of the coefficient matrix that was provided by the modified solving program used previously.

\section{RESULTS AND DISCUSSION}

Table 4 reports descriptive statistics for MY, \%Fat, \%Protein, pLF, and SCS for the studied cow population. The average daily milking production was 22.38 $\mathrm{kg} / \mathrm{d}( \pm 8.59)$. The fat and protein percentages were $4.08 \%( \pm 0.79)$ and $3.49 \%( \pm 0.41)$. Those values were similar to those of other populations studied (e.g., De Jager and Kennedy, 1987; Soyeurt et al., 2007). The $\mathrm{pLF}$ mean was $137.8 \mathrm{mg} / \mathrm{L}( \pm 176.74)$. Unfortunately, the expected concentration of LF in cows is still not clearly established (Hagiwara et al., 2003) as reported values show a large variation. The values of $\mathrm{pLF}$, our indicator trait for LF, were similar to those reported for LF by other authors. Cheng et al. (2008), who measured LF content by sandwich ELISA, obtained 115.4 $\mathrm{mg} / \mathrm{L}( \pm 67.4 ; \mathrm{n}=198)$. Hagiwara et al. (2003) used a single radial immunodiffusion test kit and obtained values higher $(169.1 \pm 2.5 \mathrm{mg} / \mathrm{L} ; \mathrm{n}=2,937)$ than those of Cheng et al. (2008), but lower than those obtained by Gaunt et al. (1980) who used an HPLC method $(236 \pm 142 \mathrm{mg} / \mathrm{L} ; \mathrm{n}=2,937)$. Soyeurt et al. (2007) found a higher mean for pLF $(189.1 \pm 155.9 \mathrm{mg} / \mathrm{L}$; 7,690 test-day records). As the calibration equation used to predict the LF content in milk was the same, the increase of the number of samples with Soyeurt et al. (2007) could explain this difference.

The model allowed the estimation of genetic, permanent environmental (within and across lactations), and residual effects. Table 5 summarizes the variances and standard errors for the studied traits: MY, \%Fat, \%Protein, pLF, and SCS. These variances were used for calculating the heritability estimates. Heritability values were $0.23,0.33$, and 0.35 for MY, \%Fat, and \%Protein, respectively (Table 6). The heritability of MY was similar to the values estimated by other authors (e.g., De Jager and Kennedy, 1987; Gengler et al., 2004). Heritability for SCS (0.13) was close to that given by Da et al. (1992) and Soyeurt et al. (2007; 0.12). Few authors have calculated the heritability of LF in bovine milk. Heritability estimated for pLF (0.22) was closed to the value obtained by Soyeurt et al. $(2007 ; 0.20, \mathrm{n}=$ 1,773). Gaunt et al. (1980) obtained a higher heritabil-

Table 5. Variances for the genetic, permanent environmental within and across lactation, and residual random effects for the studied traits: milk yield, fat percentage, protein content, predicted lactoferrin content (pLF), and SCS and their respective standard errors

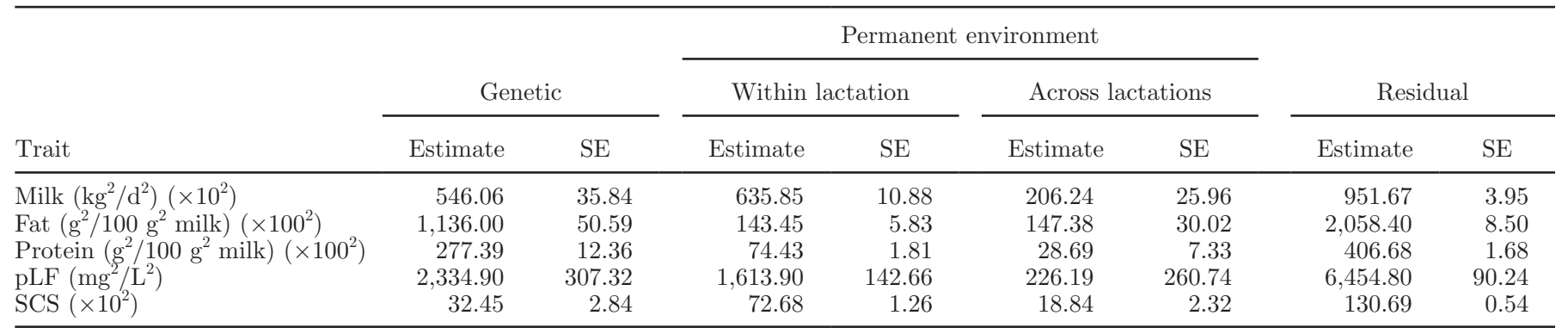


Table 6. Genetic (above the diagonal) and phenotypic (below the diagonal) correlation values (all $P$-values are $<0.0001$ ) between milk yield, milk fat percentage, milk protein percentage, predicted lactoferrin content $(\mathrm{pLF})$, and $\mathrm{SCS}^{1}$

\begin{tabular}{lrrrrr}
\hline Trait & Milk & \multicolumn{1}{c}{ Fat } & Protein & pLF & \multicolumn{1}{c}{ SCS } \\
\hline Milk $(\mathrm{kg} / \mathrm{d})$ & 0.23 & -0.33 & -0.41 & -0.25 & -0.05 \\
Fat $(\%)$ & -0.20 & 0.33 & 0.66 & 0.37 & -0.02 \\
Protein $(\%)$ & -0.31 & 0.40 & 0.35 & 0.52 & -0.02 \\
pLF (mg/L) & -0.30 & 0.14 & 0.45 & 0.22 & 0.24 \\
SCS & -0.18 & 0.06 & 0.15 & 0.31 & 0.13 \\
\hline
\end{tabular}

${ }^{1}$ Heritability values for these traits are on the diagonal.

ity for LF content measured by HPLC: 0.44 (289 cows) but obtained also larger standard errors (0.30).

Table 6 reports the genetic and phenotypic correlations among the studied traits. The estimated genetic correlation between MY and pLF was $-0.25(P<$ 0.0001 ). This observation could be explained by a dilution effect. Gaunt et al. (1980) obtained higher negative values of correlation $(-0.33 ; P<0.05)$. The genetic correlation between \%Protein and pLF was positive and moderate $(0.52 ; P<0.0001)$. This positive value was expected because of the protein nature of LF. Furthermore, this observation could be partly explained by the presence of QTL affecting protein yield and protein content in milk on BTA22 (Ashwell et al., 2004). The pLF was linked to another economic production trait: $\%$ Fat. The positive genetic correlation between pLF and $\%$ Fat was relatively moderate $(0.37 ; P<0.0001)$ and lower than the correlation estimated with \%Protein. According to Rodriguez-Zas et al. (2002), some markers located on BTA22 have a significant influence on \%Fat. The presence of these markers could explain the link existing between \%Fat and pLF. Positive estimated genetic and phenotypic correlations were observed between pLF and SCS (0.24 and 0.31, respectively; $P<$ $0.0001)$. This value seems to indicate that LF content in milk could increase in proportion to SCS. On the molecular aspect, BTA22 is known to harbor some putative QTL influencing SCC and SCS (e.g., Ashwell et al., 2004; Kaminski et al., 2006). This observation could partly explain the relationship between SCS and pLF. Furthermore, somatic cells are principally composed of leucocytes and increase in the presence of mammary inflammation such as mastitis, and LF is particularly involved in mechanism of mammary immunity. According to Harmon et al. (1976), the increase of LF in mastitis milk could be due to mammary tissue responses to inflammation or infection. This observation could be partly explained by the biological capacities of LF and suggests that LF could be a potential candidate to indicate mastitis. However, the correlation values were too low. Further research must be carried out to properly study the relationship between LF and mastitis resistance.

The PCR products obtained for the polymorphism discovery population of 20 Holstein bulls were successfully sequenced, except for exon 7, whose sequence was incompletely reported. Six SNP were detected in exons $2,4,9,11$, and 15 , and 1 in intron 8 . The polymorphisms in exons 4,9 , and 15 were also described by $\mathrm{Li}$ et al. (2004). Three new polymorphisms were detected in exon 2 (FM177941), exon 11 (FM177943), and intron 8 (FM177942). Only the SNP observed in exon 4 leads to a substitution of an isoleucine ( $A \mathrm{TC}$ ) to a valine (GTC; Li et al., 2004). The other variations were silent polymorphisms.

The allele frequency of the less-common nucleotide at each SNP was $>25 \%$ except for exon 15 and intron 8 (Table 7). Concerning the SNP located on exons 2, 4, and 9, genotypes were not in Hardy-Weinberg equilib$\operatorname{rium}\left(P\right.$-values $=2.2 \times 10^{-16}, 5.1 \times 10^{-11}$ and, $1.1 \times$ $10^{-5}$, respectively). For the other SNP, genotypes were in Hardy-Weinberg equilibrium $(P$-values $=0.35,0.07$, and 0.005 , respectively, for SNP situated on exons 11 and 15 and on intron 8).

Table 7. Allele frequency (in \%) observed for each SNP in the cow population (Pop.; $\mathrm{n}=261$ ), the studied population of cows with lowest ( $\mathrm{n}$ $=134 ;$ low $)$, and highest $(\mathrm{n}=127$; high) predicted lactoferrin content $(\mathrm{pLF}) \mathrm{EBV}$

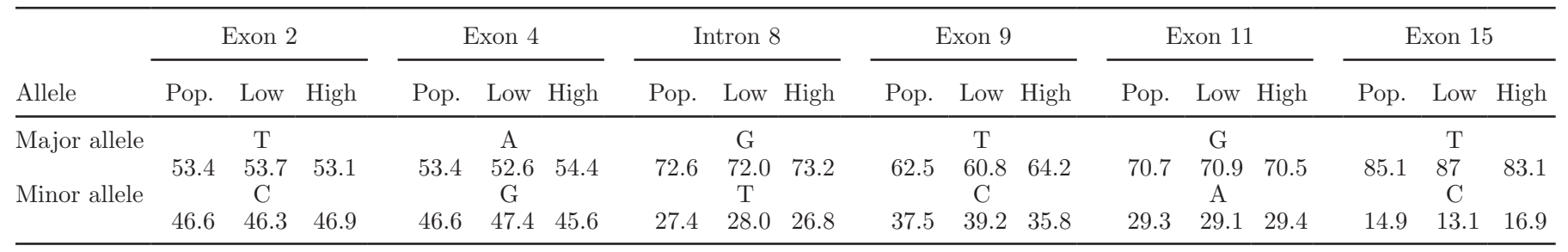


Table 8. Estimates of allele substitution effect for each studied SNP on the different traits: milk yield, fat and protein percentages, predicted lactoferrin content (pLF), and SCS, standard errors, and $P$-values obtained using a single-trait mixed model

\begin{tabular}{|c|c|c|c|c|c|c|}
\hline Item & & Milk (kg/g) & Fat (\%) & Protein (\%) & $\mathrm{pLF}(\mathrm{mg} / \mathrm{L})$ & SCS \\
\hline Exon 4 & $\begin{array}{l}\text { Estimate } \\
\text { SE } \\
P \text {-value }\end{array}$ & $\begin{array}{l}-0.144 \\
-0.361 \\
-0.691\end{array}$ & $\begin{array}{l}-0.002 \\
-0.043 \\
-0.970\end{array}$ & $\begin{array}{l}-0.030 \\
-0.021 \\
-0.163\end{array}$ & $\begin{array}{l}0.123 \\
6.375 \\
0.985\end{array}$ & $\begin{array}{l}-0.102 \\
-0.133 \\
-0.443\end{array}$ \\
\hline Exon 9 & $\begin{array}{l}\text { Estimate } \\
\mathrm{SE} \\
P \text {-value }\end{array}$ & $\begin{array}{l}-0.443 \\
-0.326 \\
-0.177\end{array}$ & $\begin{array}{l}-0.016 \\
-0.039 \\
-0.682\end{array}$ & $\begin{array}{l}-0.007 \\
-0.019 \\
-0.696\end{array}$ & $\begin{array}{r}-2.423 \\
5.765 \\
0.675\end{array}$ & $\begin{array}{l}-0.055 \\
-0.093 \\
-0.556\end{array}$ \\
\hline
\end{tabular}

Table 8 reports the allele substitution effect on pLF on the studied SNP and pLF obtained using a singletrait mixed model and based on 261 genotyped cows. No polymorphisms were significant. This lack of significance may be due to the small size of the genotyped population and the high standard errors. However, this result may be promising for additional studies using larger populations. The SNP in exons 2 and 4 had no significant effects on \%Fat and \%Protein $(0.09 ; P=$ 0.16 , and $-0.03 ; P=0.16$, respectively). The studied SNP situated on exon 2 and intron 8 also had no significant effects on pLF ( $P=0.10$ and 0.14 , respectively).

\section{CONCLUSIONS}

Improving the LF content in bovine milk could be an interesting way to increase mastitis resistance in dairy cattle and could be feasible on the basis of the estimated heritability of pLF. The negative genetic correlation $(-0.25)$ between $\mathrm{pLF}$ and MY could reflect a dilution effect. Moreover, pLF was positively correlated with \%Protein, and \%Fat (0.52 and 0.37, respectively) and, to a lower extent, with SCS (0.24). This last result may suggest LF as a potential mastitis indicator. The molecular approach revealed several polymorphisms within the bovine $L F$ gene. No significant effect was detected on the considered traits probably because of the small size of genotyped population. Nevertheless, 2 of the 6 studied SNP showed small effects on pLF in milk. The obtained results were promising and need further studies.

\section{ACKNOWLEDGMENTS}

The authors acknowledge Renée Martin (Animal and Microbial Biology Unit, Gembloux Agricultural University, Gembloux, Belgium) for her technical assistance and the Walloon Breeding Association (AWE) for its support. Nicolas Gengler, research associate, acknowledges the support of the National Fund for Scientific Research (Brussels, Belgium) by grants F.4552.05, $2.4507 .02 \mathrm{~F}(2)$ and 2.4623.08. The authors gratefully acknowledge the support of the provincial farm "Ferme de la Haye." The financial support provided by the Walloon Regional Ministry of Agriculture (Ministère de la Région Wallonne, Direction Générale de l'Agriculture, Namur, Belgium) is also acknowledged (D31-1101).

\section{REFERENCES}

Ashwell, M. S., D. W. Heyen, T. S. Sonstegard, C. P. Van Tassel, Y. Da, P. M. Van Raden, M. Ron, J. I. Weller, and H. A. Lewin. 2004. Detection of quantitative trait loci affecting milk production, health, and reproduction traits in Holstein cattle. J. Dairy Sci. $87: 468-475$

Baveye, S., E. Elass, J. Mazurier, G. Spik, and D. Legrand. 1999. Lactoferrin: A multifunctional glycoprotein involved in the modulation of the inflammatory process. Clin. Chem. Lab. Med. 37:281-296.

Boichard, D., C. Grohs, F. Bourgeois, F. Cerqueira, R. Faugeras, A. Neau, R. Rupp, Y. Amigues, M. Y. Boscher, and H. Levéziel. 2003. Detection of genes influencing economic traits in three French dairy cattle breeds. Genet. Sel. Evol. 35:77-101.

Cheng, J. B., J. Q. Wang, D. P. Bu, G. L. Liu, C. G. Zhang, H. Y. Wei, L. Y. Zhou, and J. Z. Wang. 2008. Factors affecting the lactoferrin concentration in bovine milk. J. Dairy Sci. 91:970-976.

Chenna, R., H. Sugawara, T. Koike, R. Lopez, T. J. Gibson, G. H. Desmond, and J. D. Thompson. 2003. Multiple sequence alignment 
with the Clustal series of programs. Nucleic Acids Res. 31:34973500 .

Da, Y., M. Grossman, I. Misztal, and G. R. Wiggans. 1992. Estimation of genetic parameters for somatic cell score in Holstein. J. Dairy Sci. 75:2265-2271.

De Jager, D., and B. W. Kennedy. 1987. Genetic parameters of milk yield and composition and their relationships with alternative breeding goals. J. Dairy Sci. 70:1258-1266.

Gaunt, S. N., N. Raffio, E. T. Kingsbury, R. A. Damon Jr., W. H Johnson, and B. A. Mitchell. 1980. Variation of lactoferrin and mastitis and their heritabilities. J. Dairy Sci. 63:1874-1880.

Gengler, N., G. R. Wiggans, and A. Gillon. 2004. Estimated heterogeneity of phenotypic variance of test-day yield with a structural variance model. J. Dairy Sci. 87:1908-1916.

Hagiwara, S.-I., K. Kawai, A. Anri, and H. Nagahata. 2003. Lactoferrin concentrations in milk from normal and subclinical mastitis cows. J. Vet. Sci. 65:319-323.

Harder, B., J. Bennewitz, N. Reinsch, G. Thaller, H. Thomsen, C Kühn, M. Schwerin, G. Erhardt, M. Förster, F. Reinhardt, and E. Kalm. 2006. Mapping of quantitative trait loci for lactation persistency traits in German Holstein dairy cattle. J. Anim. Breed. Genet. 123:89-96.

Harmon, R. J., F. L. Schanbacher, L. C. Ferguson, and K. L. Smith. 1976. Changes in lactoferrin, immunoglobulin G, bovine serum albumin, and $\alpha$-lactalbumin during acute experimental and natural coliform mastitis in cows. Infect. Immun. 13:533-542.

Kaminski, S., K. Olenski, P. Brym, T. Malewski, and A. A. Sazanov 2006. Single nucleotide polymorphism in the promoter region of the lactoferrin gene and its associations with milk performance traits in Polish Holstein-Friesian cows. Russ. J. Genet. 42:924-927.

Li, G. H., Y. Zhang, D. X. Sun, and L. Ning. 2004. Study on the polymorphism of bovine lactoferrin gene and its relationship with mastitis. Anim. Biotechnol. 15:67-76.
Misztal, I. 2007. BLUPF90 family of programs. University of Georgia Athens. $\quad$ http://nce.ads.uga.edu/ ignacy/numpub/blupf90/ Accessed Jan. 2, 2007.

Rainard, P., and C. Riollet. 2006. Innate immunity of the bovine mammary gland. Vet. Res. 37:369-400.

Rodriguez-Zas, S. L., B. R. Southney, D. W. Heyen, and H. A. Lewin. 2002. Detection of quantitative trait loci influencing dairy trait using a model for longitudinal data. J. Dairy Sci. 85:2681-2691.

Schwerin, M., S. S. Toldo, A. Eggen, R. Brunner, H. M. Seyfert, and R. Fries. 1994. The bovine lactoferrin gene (LTF) maps on chromosome 22 and syntenic group U22. Mamm. Genome 5:486-489.

Seyfert, H.-M., M. Henke, H. Interthal, H. Klussmann, D. Koczan, S. Natour, W. Pusch, B. Senft, U. M. Steinhoff, A. Tuckoricz, and G. Hobom. 1996. Defining candidate genes for mastitis resistance in cattle: The role of lactoferrin and lysozyme. J. Anim. Breed. Genet. 113:269-276.

Seyfert, H.-M., and C. Kühn. 1994. Characterization of a first bovine lactoferrin gene variant, based on an EcoR1 polymorphism. Anim. Genet. 25:54

Soyeurt, H. F. G. Colinet, V. M.-R. Arnould, P. Dardenne, C. Bertozzi, R. Renaville, D. Portetelle, and N. Gengler. 2007. Genetic variability of lactoferrin content estimated by mid-infrared spectrometry in bovine milk. J. Dairy Sci. 90:4443-4450.

Tosh, J. J., and J. W. Wilton. 1994. Effects of data structure on variance of prediction error and accuracy of genetic evaluation. J. Anim. Sci. 72:2568-2577.

Wakabayashi, H., K. Yamauchi, and M. Takase. 2006. Lactoferrin research, technology and applications. Int. Dairy J. 6:12411251.

Wojdak-Maksymiec, K., M. Kmiec, and J. Ziemak. 2006. Associations between bovine lactoferrin gene polymorphism and somatic cell count in milk. Vet. Med. 51:14-20. 